Dinamika Sosial Budaya, Vol 21, No. 2, Desember 2019, pp 182-187

p-ISSN: 1410-9859\& e-ISSN: 2580-8524

http://journals.usm.ac.id/index.php/jdsb

\title{
PENGARUH MEKANISME INTERNAL CORPORATE GOVERNANCE TERHADAP PEMILIHAN AUDITOR EKSTERNAL
}

\author{
Febrina Nafasati $P$ \\ Fakultas Ekonomi Universitas Semarang \\ febrina@usm.ac.id \\ Dian Indudewi \\ Fakultas Ekonomi Universitas Semarang \\ dianindudewi@usm.ac.id
}

\begin{abstract}
Abstrak
Mekanisme Corporate Governance memiliki pengaruh terhadap pemilihan auditor eksternal oleh perusahaan. Penelitian ini bertujuan untuk mengetahui pengaruh mekanisme Corporate Governance yang diproksikan dengan kepemilikan saham terbesar, ukuran dewan komisaris, efektivitas komite audit, dan proporsi dewan komisaris independen terhadap pemilihan auditor eksterna pada perusahaan non perbankan. Penelitian ini menggunakan auditor Big 4 dan auditor Non Big 4 sebagai proksi dari pemilihan auditor eksternal yang akan dipilih oleh perusahaan.

Metode analisis yang digunakan adalah Logistic Regresion. Dimana jumlah sampel yang digunakan dalam penelitian ini adalah perusahaan non perbakan yang terdaftar di Burs Efek Indonesia tahun 2013 sebanyak 177 perusahaan.

Hasil penelitian menunjukkan bahwa dewan komisaris dan efektivitas komite audit berpengaruh terhadap pemilihan auditor eksternal sedangkan komisaris independen dan kepemilikan saham terbesar tidak berpengaruh terhadap pemilihan auditor eksternal.
\end{abstract}

\section{Kata Kunci : Mekanisme Corporate Governance, pemilihan auditor eksternal}

\begin{abstract}
Internal Coporate Governance Mechanism influence for Auditor Choice. The research is to know of the impact of Internal Corporate Governance Mechanism on auditor choice by non-financial companies, where the proxies of Internal Corporate Governance Mechanism used are the largest shareholder, audit committee's effectivenese, the number of board of commissioner and the proportion of independent commissioner. This study used Top 4-non Top 4 auditor segregation as a proxy of auditor quality that will be chosen by the company.

This study used Logistic Regresion and used 177 of non financial companies listed on the Indonesia Stock Exchange 2013.

The Result showed that there are significant of the number of board of commissioner and audit committee's effectivenese on auditor choice by company. Therea are not significant of the largest shareholder and the proportion of independent commissioner on auditor choice by company.
\end{abstract}

Keyword : Corporate Governance Mechanism, Eksternal Auditor Choice 
Dinamika Sosial Budaya, Vol 21, No. 2, Desember 2019, pp 182-187

p-ISSN: 1410-9859\& e-ISSN: 2580-8524

http://journals.usm.ac.id/index.php/jdsb

\section{PENDAHULUAN}

\section{Latar Belakang}

Menurut Pernyataan Standar Akuntansi Keuangan (PSAK) Nomor 1 (Revisi 2009) tentang Penyajian Laporan Keuangan, laporan keuangan terdiri dari laporan posisi keuangan pada akhir periode, laporan laba rugi komprehensif selama periode, laporan perubahan ekuitas selama periode, laporan arus kas selama periode, catatan atas laporan keuangan, dan laporan posisi keuangan pada awal periode komparatif. Di antara kelima laporan keuangan tersebut, laporan laba rugi merupakan laporan keuangan yang sering digunakan dalam pengambilan keputusan oleh pihak internal maupun eksternal perusahaan.

Statement of Financial Accounting Concept (SFAC) No.1- Objectives of Financial Reporting by Business Enterprises yang menyatakan bahwa informasi laba merupakan indikator untuk mengukur kinerja atas pertanggungjawaban manajemen dalam mencapai tujuan operasi dan membantu pemilik memperkirakan earning power perusahaan di masa mendatang. Dikarenakan Laporan Keuangan khusunya Laporan Laba Rugi digunakan sebagai alat untuk pengambilan keputusan maka dibutuhkan adanya keandalan terhadap informasi yang disajikan dalam laporan Keuangan. Adapun cara untuk meningkatkan keandalan Laporan Keuangan yang dihasilkan oleh perusahaan adalah dengan mempergunakan jasa audit atas Laporan Keuangan. Auditor akan melaksanakan fungsi pengawasan serta menguji kredibilitas dari informasi akuntansi yang disediakan oleh manajemen (Abdel-khalik, 2001; Asbaugh \& Warfield, 2003).

Ashbaugh dan Warfield (2003) menyatakan bahwa auditor ekternal memainkan sebuah peran dalam tata kelola perusahaan sebagai alat pengawasan yang penting dalam proses pelaporan keuangan. Audit yang independen dari auditor ekternal adalah komponen penting dalam tata kelola perusahaan. Tata kelola perusahaan yang baik salah satunya diwujudkan dalam bentuk transparasi keuangan perusahaan. Tata kelola perusahaan yang baik dapat dilihat dari mekanisme tata kelola perusahaan yang diterapkan (Good Corporate Governance). Mekanisme tata kelola perusahaan (Good Corporate Governance) adalah syaratsyarat pelaksanaan sistem dalam suatu perusahaan dimana berbagai pihak yang berkepentingan terhadap perusahaan tersebut dapat memastikan pihak manajer dan pihak internal perusahaan lainnya dapat memenuhi kepentingan stakeholders ( Sanda, et al., 2005 dalam Obe, 2012 ). Dennis dan McConnell (2003) dalam Ferry (2010) membedakan mekanisme Good Corporate Governance menjadi dua bagian yaitu internal dan eksternal. Dimana Menurut Dennis dan MCConnel (2003) dalam Ferry (2010) menyebutkan bahawa mekanisme internal dilakukan oleh dewan direksi, dewan komisaris, komite audit serta struktur kepemilikan, sedangkan mekanisme eksternal lebih kepada pengaruh dari pasar untuk pengendalian pada perusahaan tersebut dan sistem hukum yang berlaku.

Auditor Eksternal memegang peranan di dalam menentukan kredibilitas suatu informasi Laporan Keuangan maka kualitas audit merupakan hal yang sangat penting. Kualitas audit merupakan faktor yang sangat sulit untuk diukur secara langsung, dimana salah satu proksi yang biasa digunakan untuk mengukur kualitas audit adalah ukuran dari kantor akuntan publik (DeAngelo, 1981; dalam Lin dan Liu (2009)). Semakin besar ukuran suatu kantor akuntan publik, maka akan lebih baik pula kualitas audit yang disediakan oleh kantor akuntan publik tersebut. Kualitas dari audit yang independen memiliki pengaruh terhadap tata kelola perusahaan. Hal ini menyebabkan pemilihan auditor merupakan keputusan penting dan harus dipertimbangkan secara matang oleh perusahaan.

Menurut Lin dan Liu (2009) selalu ada trade-off bagi perusahaan antara menggunakan auditor eksternal yang berkualitas tinggi untuk meningkatkan tata kelola perusahaan dengan menggunakan auditor berkualitas rendah untuk meneruskan opaqueness gains dari mekanisme tata kelola perusahaan yang relative rendah. Opoueness gains adalah pengungkapan yang kurang transparan, misalkan melalui praktik 
earning management. Berdasarkan Kondisi tersebut maka tujuan penelitian ini untuk melihat pengaruh mekanisme internal Corporate Governance suatu perusahaan terhadap pemilihan auditor eksternal berkualiats yang termasuk dalam kategori auditor Big Four.

\section{TINJAUAN PUSTAKA DAN HUBUNGAN LOGIS}

Wardhani (2006) menyebutkan bahwa dewan direksi dalam suatu perusahaan akan menentukan kebijakan yang akan diambil atau strategi perusahaan tersebut secara jangka pendek maupun jangka panjang dan peran dewan komisaris dalam suatu perusahaan lebih ditekankan pada fungsi monitoring dari kebijakan direksi. Chen (2005) mengungkapkan bahwa ada pengaruh positif antara ukuran dari dewan komisaris dengan level tata kelola perusahaan karena semakin banyak jumlah anggota dewan komisaris maka fungsi pengawasan dapat dilakukan secara lebih efektif. Semakin sedikit anggota dewan komisaris akan mencerminkan mekanisme $\mathrm{CG}$ yang semakin lemah sehingga akan memungkinkan adanya pengambilan keuntungan yang semakin besar oleh pemegang saham pengendali dan kemungkinan untuk memilih auditor berkualitas pun akan semakin kecil karena pemegang saham tersebut ingin mempertahankan keuntungannya. Hipotesis yang dikembangkan berdasarkan penjelasan di atas adalah:

H1: Semakin banyak jumlah anggota dewan komisaris dalam suatu perusahaan mengakibatkan peluang perusahaan tersebut untuk memilih auditor Big 4 semakin tinggi.

Forker (1992) dalam Ho dan Wong (2001) serta Nofsinger dan Mohr (2010) mengungkapkan bahwa semakin tinggi persentase dari dewan komisaris independen meningkatkan pengawasan dari kualitas pengungkapann laporan keuangan dan mengurangi keuntungan dari informasi tersembunyi. Penelitian Liu dan Lu (2007) dan Cornett (2006) juga menemukan bahwa komisaris independen secara signifikan berpengaruh negative terhadap praktek earning management. Jadi, komisaris independen berpengaruh terhadap meningkatnya pengawasan dalam tata kelola perusahaan. Dengan meningkatnya pengawasan, maka perusahaan akan cenderung tidak menerapkan opaqueness gain sehingga akan cenderung memilih auditor yang berkualitas tinggi,

Berdasarkan penjelasan di atas, dibentuklan hipotesisi sebagai berikut :

H2 : Semakin besar proporsi komisaris independen di dalam dewan komisaris suatu perusahaan mengakibatkan perusahaan tersebut untuk memilih auditor Big 4 semakin tinggi.

Tugas utama dari komite audit pada prinsipnya adalah membantu dewan komisaris dalam melakukan fungsi pengawasan atas kinerja perusahaan. Hal tersebut terutama berkaitan dengan sistem pengendalian internal perusahaan, kemudian memastikan kualitas laporan keuangan dan meningkatkan efektivitas fungsi audit yang kemudian diverifikasi oleh eksternal auditor. Dalam gambaran tersebut, dapat dikatakan bahwa komite audit berfungsi sebagai jembatan penghubung antara perusahaan dengan eksternal auditor (Balafif, 2010). Berdasarkan penjelasan di atas, dibentuklah hipotesis berikut ini:

H3: Semakin tinggi skor efektivitas komite audit dalam suatu perusahaan mengakibatkan

peluang perusahaan tersebut untuk memilih auditor Big 4 semakin tinggi.

Pemegang saham pengendali dapat memiliki komitmen yang kredibel untuk tidak melakukan ekspropriasi atas kepentingan minoritas karena adanya tingkat kepemilikan yang tinggi (Gomes,2000). Lin dan Liu (2009) dalam studinya menemukan bahwa perusahaan dengan persentase kepemilikan saham terbesar yang semakin tinggi akan memiliki kemungkinan yang lebih rendah untuk memilih auditor berkualitas karena pemegang saham pengendali ingin mempertahankan keuntungan yang mampu mereka dapatkan lewat pelaporan keuangan yang tidak transparan. Dari 
Dinamika Sosial Budaya, Vol 21, No. 2, Desember 2019, pp 182-187

p-ISSN: 1410-9859\& e-ISSN: 2580-8524

http://journals.usm.ac.id/index.php/jdsb

penjelasan di atas, maka dibentuklah hipotesis berikut ini:

H4: Semakin tinggi persentase kepemilikan saham terbesar oleh perusahaan mengakibatkan

peluang perusahaan tersebut untuk memilih auditor Big 4 semakin rendah.

\section{METODE PENELITIAN}

Variabel penelitian dalam penelitian ini terdiri dari (1) Variablel Independen yang meliputi Kepemilikan Saham Terbesar, Ukuran Dewan Komisaris, Efektivitas Komite Audit dan Proporsi Dewan Komisaris Independen (2) Variabel Dependen adalah Pemilihan Auditor Eksternal.Untuk variable kepemilikan saham terbesar diukur dari persentase kepemilikan saham dari pemegang saham tersebesar yang menunjukkan tingkat persentase dari kepemilikan lembar saham dari pemegang saham tersebesar jika dibandingkan dengan jumlah saham yang beredar. Sedangkan ukuran dewan komisaris yang diukur dengan jumlah dewan komisaris yang dimiliki oleh perusahaan. Untuk variabel efektivitas komite audit diukur dengan menggunakan checklist yang dikembangkan oleh Hermawan (2009), meliputi faktor-faktor aktivitas, jumlah anggota, dan kompetensi komite audit. Checklist ini terdiri dari 11 indikator yang masing-masing akan dinilai menjadi good, fair, dan poor. Indikator yang mendapatkan nilai good akan diberi skor 3, fair diberi skor 2, dan poor diberi skor 1 . Laporan tahunan yang tidak memuat informasi mengenai salah satu atau beberapa indikator pada checklist akan diberi skor poor, yaitu 1 .

Variabel proporsi dewan komisaris independen menunjukkan persentase dewan komisaris independen dibandingkan dengan jumlah dewan komisaris secara keseluruhan. Sedangkan pemilihan auditor eksternal dalam penelitian ini diproksikan dengan KAP Big-4 dan KAP Non Big-4 . Variabel ini merupakan variabel dummy dimana angka 1 diberikan jika auditor yang dipilih adalah auditor berkualitas tinggi (proksi:KAP Big-4), sedangkan angka 0 jika auditor yang dipilih adalah auditor yang bukan berkualitas tinggi (proksi:KAP Non Big4).

Populasi dalam penelitian ini adalah seluruh perusahaan non perbankan yang terdaftar di Bursa Efek Indonesia pada tahun 2013. Untuk menguji hipotesis di atas, maka dipilih sampel berdasarkan kriteria perusahaan non perbankan yang mempublikasikan secara lengkap laporan keuangan yang telah diaudit dan laporan tahunan tahun 2013 serta memiliki data yang lengkap yang dibutuhkan dalam penelitian ini.

Penelitian ini menggunakan model logistic Regresion karena variabel dependen yang digunakan merupakan variabel binary atau dummy. Variabel ini membedakan pemilihan auditor eksternal antara auditor eksternal yang berkualitas tinggi (KAP Big-4) dengan auditor eksternal yang berkualitas lebih rendah (KAP Non Big-4).

\section{HASIL DAN PEMBAHASAN}

Jumlah perusahaan non perbankan tahun 2013 yang terdaftar di Bursa Efek Indonesia sebanyak 400 perusahaan. Dari jumlah ini 223 perusahaan tidak memiliki data lengkap yang dibutuhkan dalam penelitian ini. Sehingga jumlah sampel yang digunakan adalah sebanyak 177 perusahaan.

Kelayakan model regresi dinilai dengan menggunakan Hosmer and Lemeshow's Goodness of Fit Test. Hosmer and Lemeshow's Goodness of Fit Test menguji hipotesis nol bahwa data empiris cocok atau sesuai dengan model (tidak ada perbedaan antara model dengan data sehingga model dapat dikatakan fit). Hasil Hosmer and Lemeshow's Goodness of Fit Test diperoleh nilai Chi-square sebesar 9,557 dengan nilai signifikan 0,297 dan derajat bebas (df) 8. Dari hasil tersebut terlihat bahwa nilai signifikansi lebih besar dari $\mathrm{a}=0,05$ Sehingga dapat disimpulkan bahwa pada model regresi logistik yang telah digunakan memenuhi kecukupan data (fit).

Penilaian keseluruhan model dilakukan dengan membandingkan nilai antara -2 Log Likelihood (-2LL) pada awal (Block Number $=$ 0 ), dimana model hanya memasukkan konstanta 
Dinamika Sosial Budaya, Vol 21, No. 2, Desember 2019, pp 182-187

p-ISSN: 1410-9859\& e-ISSN: 2580-8524

http://journals.usm.ac.id/index.php/jdsb

dengan nilai -2 Log Likelihood (-2LL) pada akhir (Block Number $=1)$, dimana model memasukkan konstanta dan variabel bebas. Nilai -2LL awalnya adalah sebesar 243.331 dan setelah dimasukan keenam variabel independen, maka nilai -2LL akhir mengalami penurunan menjadi sebesar 222.586. Penurunan nilai -2LL ini menunjukkan bahwa model regresi yang baik atau dengan kata lain model yang dihipotesiskan fit dengan data. Besarnya nilai koefisien determinasi pada model regresi logistik ditunjukkan dengan nilai Nagelkerke $R$ square. Nilai Nagelkerke $R$ square adalah sebesar 0,148 yang berarti variabilitas variabel dependen yaitu pemilihan auditor eksternal dapat dijelaskan oleh variabel independen yaitu variabel ukuran dewan komisaris (UDK), Proporsi Dewan Komisaris Independen (KI), efektivitas komite audit (efektivitas), dan kepemilikan saham (saham) adalah sebesar $14,8 \%$ persen, sedangkan sisanya sebesar $86,2 \%$ dijelaskan oleh variabel-variabel lain diluar model penelitian.

Hasil pengujian hipotesis untuk Hipotesis pertama hasil pengujian menunjukkan tingkat signifikansi 0,005 yang berarti lebih kecil dari 0,05. Yang berarti variabel ukuran dewan komisaris berpengaruh terhadap pemilihan audit eksternal. Hasil ini sesuai dengan teori keagenan dimana terdapat perbedaan kepentingan antara principal dalam hal ini pemilik dan investor dengan agen yaitu pihak manajemen perusahaan. Beda kepentingan ini dijembatani dengan adanya dewan komisaris sebagai pihak yang bertugas mengawasi manajemen perusahaan agar meminimalkan asimetris informasi yang terjadi antara pihak principal dengan agen sehingga semakin besar anggota dewan komisaris maka perusahaan akan memilih auditor eksternal yang berasal dari KAP Big 4 yang lebih berkualitas, dan sebaliknya semakin sedikit anggota dewan komisaris maka perusahaan cenderung akan memilih auditor eksternal dari KAP Non Big 4. Hasil peneelitian ini konsisten dengan hasil penelitian yang dilakukan oleh Lin Ming (2007) dan Giuseppe (2013) yang menunjukkan bahwa ukuran dewan komisaris berpengaruh terhadap pemilihan auditor berkualitas.
Hipotesis kedua hasil pengujian menunjukkan tingkat signifikansi 0,213 yang berarti lebih besar dari 0,05. Sehingga dapat disimpulkan bahwa variabel komisaris independen tidak berpengaruh terhadap pemilihan auditor eksternal. Hasil ini menunjukan bahwa jumlah komisaris independen yang dimiliki oleh suatu perusahaan tidak mempengaruhi di dalam pemilihan auditor eksternal. Sehingga dapat dikatakan bahwa pada perusahaan yang memiliki jumlah komisaris independen lebih besar maka perusahaan cenderung untuk memilih auditor non big four. Sesuai dengan pernyataan Giuseppo (2013) bahwa auditor berkualiats salah satunya dilihat dari independensi auditor. Dengan auditor non big four yang independensinya bisa dipengaruhi maka manajemen perusahaan dapat mempengaruhi independensi auditor non Big Four di dalam melaksanakan pekerjaannya sehingga perusahaan akan cenderung menerapkan opaqueness gain dalam pelaporan keuangannnya karena penunjukkan dewan komisaris independen dalam suatu badan usaha dilakukan oleh pihak manajemen perusahaan sehingga jika seorang komisaris independen tidak setuju dengan keputusan yang dibuat oleh pihak manajemen maka perusahaan dapat menggantikan posisi komisaris independen tersebut dengan orang lain (Murhadi,2009). Atau penempatan anggota dewan komisaris independen hanya sekedar memenuhi ketentuan formal dan peraturan Bapepam dan tidak dimaksud untuk menegakkan Good Corporate Governance dalam suatu badan usaha (Ujiyantho dan Pramuka,2007). Hasil ini mendukung penelitian yang dilakukan oleh Obe (2012) menyatakan komisaris independen tidak berpengaruh terhadap pemilihan auditor eksternal.

Hasil pengujian hipotesis ketiga menunjukkan tingkat signifikansi 0,003 yang berarti lebih kecil dari 0,05. Berdasarkan hal tersebut dapat disimpulkan bahwa variabel efektivitas komite audit berpengaruh terhadap pemilihan audit eksternal .Semakin efektif komite audit maka komite audit akan menunjuk auditor eksternal yang berkualitas (Auditor Big Four). Hal ini disebabkan karena komite audit 
ingin menjalankan fungsinya, diantaranya mengawasi proses pelaporan keuangan dengan baik yang kemudian akan berimplikasi pada penunjukan auditor eksternal berkualitas (Balafif,2010). Fungsi dari komite audit adalah memastikan bahwalaporan keuangan yang disajikan untuk pihak eksternal telah melalui proses audit eksternal yang memadai. Selain itu fungsi dari komite audit juga mengevaluasi atas lingkup kerja, keakuratan, efektiitas biaya, independensi dan obyektivitas dari auditor ekternal. Sehingga semakain efektif komite audit suatu perusahaan maka komite audit akan menunjuk auditor eksternal yang masuk kategori Big Four. Karena Auditor Big Four dapat diartikan sebagai audit yang berkualitas, dimana kualitas audit tergantung pada kompetensi professional dan independensi auditor. Dengan memilih auditor Big Four maka akan memberikan jaminan kepada komite audit bahwa audit laporan keuangan perusahaan dilakukan dengan baik. Hasil penelitian ini mendukung hasil peneltian Balafif (2010) yang menyatakan bahwa efektivitas komite audit berpengaruh terhadap pemilihan auditor eksternal yang berkualitas.

Pada Hipotesis keempat hasil pengujian ini menunjukkan tingkat signifikansi 0,693 yang berarti lebih besar dari 0,05 . Ini berarti bahwa variabel struktur kepemilikan saham terbesar tidak berpengaruh terhadap pemilihan auditor eksternal. Hasil ini mengindikasikan bahwa baik besar ataupun kecil kepemilikan saham tidak dijadikan dasar bagi perusahaan dalam memilih auditor eksternal. Hal ini dikarenakan pemegang saham lebih menitikberatkan kepada tingkat pengembalian yang dapat mereka peroleh bukan pada berkualitas tidaknya auditor yang mengaudit laporan keuangan. Dikarenakan pemegang saham menitikberatkan kepada tingkat pengembalian yang akan mereka peroleh maka pemegang saham terbesar berusaha mempertahankan keuntungan yang mereka peroleh dengan melalui ketidak tranparannya laporan keuangan perusahaan. Giuseppe (2013) menyatakan bahwa klasifikasi auditor big four dan auditor non big four berhubungan dengan kualitas, auditor big four memiliki kualitas yang lebih tinggi dibandingkan dengan auditor non big four. De Angelo (1981) dalam Giuseppe (2013) mendefinisikan kualitas audit sebagai kemungkinan auditor mendeteksi adanya kesalahan atau kecurangan dan melaporkan hal tersebut kepada publik melalui laporan audit. Dengan kata lain kualitas audit tergantung pada kompetensi professional dan independensi auditor. Ini berati auditor non Big Four dapat diartikan sebagai audit yang tidak berkualitas dimana kompetensi professional dan independensi dari auditor non big four diragukan. Sehingga dikarenakan pemegang saham terbesar berusaha mempertahankan keuntungan yang mereka peroleh dengan melalui ketidak transparannya laporan keuangan perusahaan dengan memilih auditor yang tidak berkualitas atau auditor non Big Four. Hasil penelitian ini mendukung hasil penelitian Liu (2007) yang menyatakan semakin besar persentase kepemilikan maka auditor eksternal yang dipilih adalah auditor kecil.

\section{SIMPULAN DAN SARAN}

Berdasarkan hasil penelitian maka secara umum dapat disimpulkan bahwa tidak semua mekanisme internal Corporate Governance dapat mempengaruhi perusahaan di dalam pemilihan auditor eksternal . Dari empat mekanisme internal Corporate Governance yang digunakan dalam penelitian ini, ukuran dewan komisaris dan efektivitas komite audit berpengaruh terhadap pemilihan auditor eksternal (Big Four) sedangkan komisaris independen dan kepemilikan saham terbesar tidak berpengaruhi terhadap pemilihan auditor eksternal (Big Four).

Hasil ini sesuai dengan teori keagenan dimana terdapat perbedaan kepentingan antara principal dalam hal ini pemilik dan investor dengan agen yaitu pihak manajemen perusahaan. Beda kepentingan ini dijembatani dengan adanya dewan komisaris dan efektivitas komite audit sebagai pihak yang bertugas mengawasi manajemen perusahaan agar meminimalkan asimetris informasi yang terjadi antara pihak principal dengan agen sehingga perusahaan akan memilih auditor eksternal yang berkualitas (Big Four). Sedangkan komisaris independen dan 
kepemilikan saham terbesar tidak bisa menjembatani adanya beda kepentingan antara principal dan agen.

Sehubungan dengan hasil penelitian yang berkaitan dengan pemilihan auditor eksternal agar manajemen perusahaan dalam menjalankan operasional perusahaan sebaiknya juga memperhatikan tata kelola perusahaan. Auditor eksternal adalah komponen penting dalam tata kelola perusahaan. Dimana fungsi dari auditor eksternal adalah memberikan keyakinan mengenai laporan keuangan yang dihasilkan oleh perusahaan. Sehingga sangatlah penting memperhatikan dalam hal pemilihan auditor eksternal yang berkualitas.

Meskipun penelitian ini sudah berusaha secara maksimal untuk melihat faktor-faktor apa saja yang mempengaruhi pemilihan auditor internal, namun masih tetap memiliki keterbatasan dalam penelitian ini, diantaranya adalah sebagai berikut :

1. Adanya unsur subyektivitas dalam mengukur indikator efektivitas komite audit sehingga dimungkinkan terjadi bias dalam penelitian.

2. Penelitian ini masih memiliki hasil Nagelkerke $\mathrm{R}$ Square yang kecil yaitu 14,8\%. Hasil ini menunjukkan bahwa masih banyak faktor lain yang dapat digunakan oleh perusahaan dalam memilih auditor eksternal.

3. Tahun pengamatan yang digunakan hanya 1 tahun yaitu 2013

Adanya keterbatasan pada penelitian ini, maka untuk agenda penelitian yang akan datang diharapkan agar dapat menambah jumlah sampel supaya hasilnya lebih akurat serta memasukkan variabel lain untuk memprediksi pemilihan auditor eksternal seperti kepemilikan manajerial,

\section{Daftar Pustaka}

Abdel-khalik, A. R. (2001). Reforming Corporate Governance after Enron: Shareholders' Board of Trustees and the Auditor. Journal of Accounting Public Policy, 97-119.

Asbaugh, H., \& Warfield, T. D. (2003). Audits as a Corporate Governance Mechanism :
Evidence from the German Market. Journal of International Accounting Research, 121.

Arens (2011). Jasa Audit dan Assurance. Terjemahan. Pendekatan Terpadu (Adaptasi Indonesia). Salemba Empat Jakarta

Balafif, S. (2010). Pengaruh Efektifitas Komite Audit, Ukuran Perusahaan, Kepemilikan Keluarga, dan Kepemilikan Asing terhadap Pemilihan Auditor Eksternal Berkualitas. Tesis FEUI.

Claessens, S., Djankov, S., Fan, J. P., \& Lang, L. H. (2002). Disentangling the Incentive and Entrenchment Effects of Large Shareholdings. Journal of Finance 57 , 2741-2771.

Cornett. M. M., Allan J. M., Anthony S., dan Hasan T (2006). [Online]. Earning Management, Corporate Governance, and True Financial Performance. Available : http://papers.ssrn.com/sol3/papers.cfm? Abstract_id $=886142$.

Giuseppe Ianniello et.al (2013). Corporate Governance And Auditor Choice. Paper. Bicentenary Coference- Lecce, Italy, September 19-21, 2013.

Gomes, A. (2000). Going Public without Governance: Managerial Reputation Effects. The Journal of Finance Vol LV, No. 2, 615-646.

Lin, Z. J., \& Liu, M. (2009). The Impact of Corporate Governance on Auditor Choice:Evidence from China. Journal of International Accounting, Auditing and Taxation $18,44-59$.

LIU Ming (2007). Corporate Governance, Auditor Choice And Auditor Switch. Thesis. Hongkong Baptist University.

Mulyadi (2002). Auditing. Edisi ke-6. Cetakan ke-1. Maret 2002. Salemba Empat. Jakarta

Schleifer, A., \& Vishny, R. W. (1996). A Survey of Corporate Governance. National Bureau of Economis Researh .

Wardhani, R. (2006). Mekanisme Corporate Governance dalam Perusahaan yang Mengalami Permasalahan Keuangan. Simposium Nasional Akuntansi . 